\title{
Pengembangan LKS Berbentuk Komik Pada Materi Program Linear Berbasis Penemuan Terbimbing Pada Kelas XI SMK Wisnuwardhana Malang
}

\author{
1Oktavianus Bumma, ${ }^{2}$ Nia Wahyu Damayanti ${ }^{3}$ Muhammad Baidawi \\ 1,2,3Program Studi Pendidikan Matematika, FKIP, Universitas Wisnuwardhana Malang, Indonesia \\ ${ }^{1}$ Email: arline.yulinda@gmail.co.id
}

\begin{abstract}
Learning tools are one important aspect to determine the success of a learning design. Student worksheet is one of the learning tools. The purpose of this study is as follows. 1) to find out how to develop a mathematics learning worksheet in the form of comics based on guided discovery on linear program material, 2) to find out the validity and practicality of a mathematics learning worksheet in the form of comics based on guided discovery on linear program material. In this research the method used is the development method. So the research explained that what was developed was a comic-based worksheet based on guided findings on linear program metrics. The subjects in this study were students of class XI Vocational School Wisnuwardhana Malang. Based on the LKS development research results that have been obtained that the validity results assessed by three validator experts are 1) material expert validator, 2) media expert validator, and 3) linguist validator reaches a percentage of $72.20 \%$. In this criterion, the worksheets that were developed were good (valid) and the results of practicality were obtained from the student questionnaire responses and obtained an average value of 3.3 which in this criterion was declared good (practical). From the development of LKS in the form of comics based on guided discoveries on linear program material, it was concluded that the development of LKS is valid and practical so that it is suitable to be used in mathematics learning.
\end{abstract}

Keyword: Development of LKS Based on Comic, Guided Discovery, Linear Program Material

\begin{abstract}
Abstrak: Perangkat pembelajaran merupakan salah satu aspek penting untuk menentukan kesuksesan dari suatu desain pembelajaran. Lembar Kerja Siswa merupakan salah satu perangkat pembelajaran. Tujuan dari penelitian ini adalah sebagai berikut. 1) untuk mengetahui cara mengembangkan LKS pembelajaran matematika berbentuk komik berbasis penemuan terbimbing pada materi program linear, 2) untuk mengetahui kevalidan dan kepraktisan LKS pembelajaran matematika berbentuk komik berbasis penemuan terbimbing pada materi program linear. Dalam penelitian ini metode yang digunakan adalah metode pengembangan. Sehingga pada penelitian dijelaskan bahwa yang dikembangkan adalah LKS berbentuk komik berbasis penemuan terbimbing pada metri program linear. Subjek dalam penelitian ini adalah siswa kelas XI SMK Wisnuwardhana Malang. Berdasarkan hasil penelitian pengembangan LKS yang telah diperoleh bahwa hasil kevalidan yang dinilai oleh tiga ahli validator yaitu 1) validator ahli materi, 2) validator ahli media, dan 3) validator ahli bahasa mencapai persentase $72,20 \%$. Pada kriteria ini LKS yang dikembangkan baik (valid) dan hasil kepraktisan diperoleh dari angket respon siswa dan memperoleh nilai rata-rata 3,3 dimana pada kriteria ini dinyatakan baik (praktis). Dari pengembangan LKS berbentuk komik berbasis penemuan terbimbing pada materi program linier disimpulkan bahwa pengembangan LKS ini valid dan praktis sehingga layak digunakan dalam pembelajaran matematika.
\end{abstract}

Kata Kunci: Pengembangan LKS Berbentuk Komik, Penemuan Terbimbing, Materi Program Linear. 


\section{PENDAHULUAN}

Perkembangan jaman yang semakin modern terutama pada era globalisasi seperti sekarang ini menuntut adanya sumber daya manusia yang berkualitas tinggi. Peningkatan sumber daya manusia merupakan persyaratan mutlak untuk mencapai tujuan pembangunan. Salah satu dasar untuk meningkatkan kualitas sumber daya manusia yaitu pendidikan. Pendidikan di Indonesia memilki peran yang sangat penting yang berkaitan dengan mutu pendidikan. Hal ini juga sesuai dengan undang-undang nomor 20 tahun 2003 tentang Sistem Pendidikan Nasional pada pasal 3, yang menyebutkan bahwa pendidikan nasional berfungsi mengembangkan kemampuan dan membentuk karakter serta peradaban bangsa yang bermartabat dalam rangka mencerdaskan kehidupan bangsa. Peningkatan mutu pendidikan sangat penting untuk mengantisipasi perkembangan teknologi yang tidak terlepas dari perkembangan matematika. Matematika merupakan ilmu umum yang mendasari perkembangan teknologi modern. Perkembangan pesat dibidang teknologi informasi dan komunikasi dewasa ini, tidak terlepas dari peran perkembangan matematika. Sehingga, untuk dapat menguasai dan mencipta teknologi serta bertahan dimasa depan diperlukan penguasaan matematika yang kuat sejak dini (Depdiknas, 2004). Kurikulum 2013 menuntut kreativitas guru dalam menyelenggarakan kegiatan pembelajaran. Pembelajaran harus diarahkan untuk membentuk siswa terbiasa berfikir kreatif, menyelesaikan masalah, membuat keputusan, menalar dan menyampaikan ide-idenya. Namun masih terdapat kesulitan dalam penerapan kurikulum 2013 karena keterbatasan pengetahuan dan wawasan guru terkait dengan konsep pembelajaran, belum ada guru yang mencoba untuk membuat bahan ajar, serta sekolah tidak mempunyai buku yang dapat dipinjam oleh siswa.

Kegiatan pembelajaran yang diinginkan kurikulum 2013 adalah pembelajaran yang berpusat pada siswa (student centered learning). Siswa dituntut untuk aktif dan senantiasa ambil bagian dalam kegiatan belajar. Siswa akan bosan jika setiap pembelajaran menggunakan buku teks yang sama, sehingga guru yang kreatif harus menyajikan materi dalam bentuk yang dapat diserap dan dinikmati siswa Siswa akan memahami materi dengan baik apabila siswa belajar materi tersebut secara mandiri. Salah satu alternatif bahan ajar yang perlu dikembangkan untuk mengarahkan pola pikir siswa dan membangun kemandirian siswa adalah Lembar Kerja Siswa (LKS). LKS berisi tugas dan langkah-langkah yang menuntun siswa mengelola pola pikir secara terarah. Peran guru sebagai fasilitatorpun dapat dimaksimalkan. Dengan LKS diharapkan siswa dapat belajar secara mandiri, memahami dan menjalankan suatu secara tertulis (Majid,2008).

Lembar Kerja Siswa (LKS) merupakan salah satu bahan ajar cetak yang sampai saat ini masih banyak digunakan oleh guru. LKS dipilih sebagai perangkat pembelajaran yang dikembangkan karena LKS memiliki fungsi antara lain sebgai bahan ajar yang bisa memudahkan peserta didik dalam memahami materi yang diberikan, meminimalkan peran guru tetapi lebih mengaktifkan peserta didik (Prastowo dalam Afarit, 2012).

. Tujuan penelitian ini adalah mengembangkan LKS program linier dalam bentuk komik untuk mengatasi kesulitan siswa dalam mencari bahan ajar yang dapat digunakan siswa secara mandiri. Bahan ajar pembelajaran yang didalamnya menyajikan permasalahan dalam kebidupan nyata. LKS yang berbentuk komik disesuaikan dengan kondisi siswa karena komik dapat membawa kesenangan bagi siswa sehingga praktis dan mudah dibawa kemana saja.

\section{METODE}

Dalam penelitian ini, peneliti menggunakan desain pengembangan model ADDIE. Model pengembangan ini dikembangkan oleh Reaser dan Molenda. Salah satu fungsinya ADDIE yaitu menjadi pedoman dalam membangun perangkat dan infrastruktur program 
penelitian yang efektif, dinamis dan mendukung kinerja pelatihan itu sendiri. Model ini sesuai dengan namanya, terdiri dari lima tahap utama, yaitu (A) anaysis, (D) design, (D) development, (I) implemention, (E) evaluation.

\section{HASIL DAN PEMBAHASAN}

\section{A. Hasil Tahap Implementasi}

Pada tahap ini, peneliti memberika angket respon terhadap siswa Kelas XI untuk mengetahui respon siswa terhadap LKS. Dalam hal ini, peneliti membagikan angket kepada 10 peserta didik yang bertujun untuk mengetahui kevaidan dan kepraktisan dari pada LKS. Penilaian LKS oleh pesserta didik dilalukan dengan cara meminta siswa untuk mengisi angket yang telah disiapkan oleh peneliti. Tahap ini dilakukan untuk mengetahui kevalidan dan kepraktisan dari produk yang telah dikembangkan oleh peneliti.

\section{Tabel 1. Hasil Kepraktisan LKS}

\begin{tabular}{|c|c|c|c|}
\hline No. & Aspek & Skor & Kriteria \\
\hline 1 & $\begin{array}{l}\text { LKS ini menjelaskan suatu konsep menggunakan ilustrasi masalah } \\
\text { yang berkaitan dengan kehidupan sehari-hari }\end{array}$ & 4 & SS \\
\hline 2 & $\begin{array}{l}\text { LKS ini menggunakan contoh-contoh soal yang berkaitan dengan } \\
\text { kehidupan sehari-hari }\end{array}$ & 3 & B \\
\hline 3 & $\begin{array}{l}\text { Apakah anda setuju jika LKS berbentuk komik berbasis penemuan } \\
\text { terbimbing diterapkan disekolah? }\end{array}$ & 4 & SS \\
\hline 4 & $\begin{array}{l}\text { Apakah anda senang jika pembelajaran matematika menggunakan LKS } \\
\text { berbentuk komik berbasisis penemuan terbimbing? }\end{array}$ & 4 & SS \\
\hline 5 & $\begin{array}{l}\text { Apakah penerapan LKS berbentuk komik berbasis penemuan } \\
\text { terbimbing berguna bagi anda dalam mempelajari materi yang ingin di } \\
\text { capai? }\end{array}$ & 4 & SS \\
\hline 6 & $\begin{array}{l}\text { Apakah LKS berbentuk komik berbasis penemuan terbimbing menarik } \\
\text { bagi anda? }\end{array}$ & 3 & B \\
\hline 7 & $\begin{array}{l}\text { Apakah dengan LKS berbentuk komik berbasis penemuan terbimbing } \\
\text { membantu anda untuk lebih mudah memahami materi yang telah } \\
\text { dipelajari? }\end{array}$ & 3 & B \\
\hline 8 & $\begin{array}{l}\text { Apakah dengan LKS berbentuk komik berbasis penemuan terbimbing } \\
\text { membantu anda untuk lebih mudah memahami materi yang telah } \\
\text { dipelajari? }\end{array}$ & 4 & SS \\
\hline 9 & $\begin{array}{l}\text { Apakah dengan LKS berbentuk komik berbasis penemuan terbimbing } \\
\text { dapat menunjang pembelajaran anda di sekolah? }\end{array}$ & 4 & SS \\
\hline 10 & $\begin{array}{l}\text { Apakah dengan LKS berbentuk komik berbasis penemuan terbimbing } \\
\text { waktu yang anda gunakan lebih efisien? }\end{array}$ & 4 & B \\
\hline 11 & $\begin{array}{l}\text { Adakah kesulitan dalam memahami pelajaran matematika jika } \\
\text { menggunakan LKS berbentuk komik berbasis penemuan terbimbing? }\end{array}$ & 4 & SS \\
\hline \multirow[t]{2}{*}{12} & $\begin{array}{l}\text { Apakah latihan soal pada LKS berbasis penemuan terbimbing sudah } \\
\text { cukup memberikan pemahaman mengenai materi tersebut?matematika } \\
\text { tidak membosankan }\end{array}$ & 4 & SS \\
\hline & Rata-rata & 3,3 & \\
\hline
\end{tabular}

Berdasarkan hasil penilaian angket respon siswa terhadap Lembar Kerja siswa berbentuk komik berbasis penemuan terbimbing pada siswa kelas XI TJK wisnuwardahana malang terhadap program linier, rata-rata yang didapatkan dari angket respon siswa adalah 3,3, rata-rata yang didapatkan dari pengembangan Lembar Kerja Siswa (LKS) dikatakan praktis. 


\section{B. Deskripsi Hasil Pengembangan Produk}

a. Potensi Masalah

Tahap selanjutnya melakukan observasi dan wawancara terhadap kondisi pembelajaran dan LKS yang digunakan dalam pembelajaran matematika di SMK Wisnuwardhana Malang bahwa pembelajaran dan LKS terlalu monoton sehingga peserta didik merasa bosan dan jenuh untuk belajar.

b. Pengumpulan Data

Setelah potensi masalah di identifikasi, langkah selanjutnya yang dilakukan adalah tahap pengumpulan data. Pengumpulan data dilakukan untuk memperoleh apa yang dibutuhkan siswa terhadap produk yang ingin dikembangkan. Langkah pertama yang dilakukan oleh peneliti adalah menganalisis perkembangan siswa siswi SMK Wisnuwardhana Malang. Berdasarkan hasil penelitian tetrhadap siswa-siswi sangat tertarik oleh pembelajaran menggunakan metode penemuan terbimbing dengan berbentuk komik sehingga dapat membantu siswa mengingat materi pembelajaran matematika. Setelah melakukan analisi terhadap siswa siswi SMK Wisnuwardhana Malang peneliti melakukan analisis materi, materi dalam pengembangan produk iniadalah materi semester ganjil kelas XI kurikulum 2013 lebih menekankan siswa untuk aktif sehingga materi matematika yang dipilih adalah materi program linier.

\section{Deskripsi Hasil Validasi Desain Oleh Para Ahli}

Validasi desain dilkukan oleh tiga orang dosen matematika yang sudah berpengalaman dan memiiki gelar kurang lebih S2 dan S3 dalam meniai bahan ajar yang telah dibuat oleh peneliti. Dalam validasi desain produk ini terdiri dar tiga dosen yaitu Dr. Abdul Hamid Bachtiar, M.Pd selaku ahli media, Febi Dwi Widayati, M.Pd selaku ahli bahasa dan Cynthia Tri Octavianti, M.Pd. selaku ahli materi. Berikut adalah hasil validasi oleh ahli media, ahli bahasa dan ahli materi.

\section{a. Deskripsi Hasil Validasi Desain Oleh Ahli Materi.}

Produk pengebangan yang diserahkan kepada ahli materi matematika adalah berupa media pembelajaran. Paparan deskriiptif oleh ahli materi akan ditnjukkan melalui metode kuisioner dengan instrumen angket. Instrumen yang digunakan dala pengumpulan data adalah angket uji validasi yang disusun menurut Arikunto (2010).yaitu 1 = Kurang Sekali, 2 = Kurang, $3=$ Cukup, $4=$ Baik, 5 = Sangat Baik. Analisis data dengan menentukan skor tertinggi dan menjumlahkan skor dari masing-masing validator dapat dilihat dari tabel dibawah ini.

Tabel 2. Hasil Validasi Ahli Materi

\begin{tabular}{llcc}
\hline No. & \multicolumn{1}{c}{ Aspek } & Nilai & Ahli Media \\
\hline 1. & Kesesuaian materi dengan KD & SB & $\frac{4}{5} \times 100 \%=80 \%$ \\
2. & Keakuratan materi & B & $\frac{3,75}{5} \times 100 \%=75 \%$ \\
3. & Kemuktahiran materi & SB & $\frac{4,5}{5} \times 100 \%=90 \%$ \\
4. & Mendorong keingintahuan & SB & $\frac{4}{5} \times 100 \%=80 \%$ \\
\hline
\end{tabular}

Aspek yang dinilai oleh ahli materi adalah aspek kesesuaian materi dengan KD, keakuratan materi, kemuktahiran materi dan mendorong keingintahuan. Penilaian ahli validator materi terhadap aspek kesesuaian materi dengan KD diperoleh hasil 80\%. Pada aspek keakuratan materi diperoleh hasil $75 \%$. Pada aspek kemuktahiran materi oleh ahli validator materi diperoleh hasil $90 \%$. Sedangkan pada aspek mendorong keingintahuan diperoleh hasil $80 \%$. Kesimpulannya adalah bahwa LKS yang di validasi oleh ahli meteri 
berada pada kriteria Valid atau layak digunakan dalam pembelajaran matematika pada materi program linier.

\section{b. Deskripsi Data Hasil Validasi Oleh Ahli Media}

Produk pengembangan yang diserahkan kepada ahli pembelajaran adalah media pembelajaran. Aspek yang dinilai oleh ahli media adalah aspek format, organisasi, gaya tarik, ukuran huruf, bahasa dan konsistensi. Menurut skala skor oleh Suharsimi Arikunto (2010) kriteria skor peneliaian dapat dilihatpada tabel berikut.

Tabel 3. Hasil Validasi Oleh Ahli Media

\begin{tabular}{llll}
\hline No. & \multicolumn{1}{c}{ Aspek } & Nilai & \multicolumn{1}{c}{ Ahli Media } \\
\hline 1. & Desain sampul LKS & B & $\frac{3,87}{5} \times 100 \%=77,4 \%$ \\
2. & Desain isi LKS & B & $\frac{3,25}{5} \times 100 \%=65 \%$ \\
3. & Materi & B & $\frac{3,75}{5} \times 100 \%=75 \%$ \\
\hline
\end{tabular}

Dari hasil penilaian oleh validator ahli media pada aspek desain sampul LKS diperoleh hasil $77,4 \%$. Pada aspek desain isi LKS yang dinilai oleh ahli validator media diperoleh skor $65 \%$. Sedangkan pada aspek materi perolehan nilai oleh ahli validator diperoleh $75 \%$. Dalam hal ini LKS yang telah divalidasi oleh ahli media termasuk kriteria valid atau layak digunakan dalam pembelajaran matematika pada materi program linier.

\section{c. Deskripsi Data Hasil Validasi Oleh Ahli Bahasa}

Produk pengembangan yang diserahkan kepada ahli bahasa adalah produk media pembelajaran LKS. Aspek yang dinilai adalah aspek bahasa, apakah bahasa yang digunakan mudah dimengerti dan dipahami oleh peserta didik atau tidak.

\section{Tabel 4. Hasil Validasi Oleh Ahli Bahasa}

\begin{tabular}{llcc}
\hline No. & \multicolumn{1}{c}{ Aspek } & Nilai & Ahli Bahasa \\
\hline 1. & Lugas & SB & $\frac{4}{5} \times 100 \%=80 \%$ \\
2. & Komunikatif & SB & $\frac{4}{5} \times 100 \%=80 \%$ \\
3. & Dialogis dan interaktif & SB & $\frac{4}{5} \times 100 \%=80 \%$ \\
4. & Kesesuaian dengan perkembangan siswa & SB & $\frac{4}{5} \times 100 \%=80 \%$ \\
5. & Kesesuaian dengan kaidah bahasa & B & $\frac{3,5}{5} \times 100 \%=70 \%$ \\
6. & Penggunaan istilah, simbol atau ikon & SB & $\frac{4}{5} \times 100 \%=80 \%$ \\
\hline
\end{tabular}

Berdasarkan tabel di atas, dapat dilihat perolehan skor tiap aspek dimana pada aspek lugas hasil validasi oleh ahli media diperoleh skor $80 \%$. Pada aspek komunikatif diperoleh hasil 80\%.Pada aspek dialogis dan interaktif diperoleh skor $80 \%$. Pada aspek kesesuaian dengan perkembangan siswa diperoleh hasil $80 \%$. Pada aspek kesesuaian dengan kaidah bahasa diperoleh skor 70\%. Sedangkan pada aspek penggunaan istilah dengan kaidah bahasa diperoleh skor $80 \%$. Dalam hal ini dapat disimpulkan bahwa LKS yang telah divalidasi oleh ahli bahasa termasuk pada kriteria valid atau layak di digunakan dalam pembelajaran matematika pada matapelajaran program linier. 
Tabel 5. Hasil Validasi Layak Uji Coba

\begin{tabular}{ccc}
\hline No. & \multicolumn{1}{c}{ Validator } & Jumlah Persentase (\%) \\
\hline 1. & Ahli materi & $80 \%$ \\
2. & Ahli media & $68,33 \%$ \\
3. & Ahli bahasa & $78,33 \%$ \\
& Rata-rata & $72,20 \%$ \\
\hline
\end{tabular}

Berdasarkan hasil validasi diperoleh skor rata-rata seluruh aspek pengembangan Lembar Kerja Siswa (LKS) berbentuk komik berbasis penemuan terbimbing persentase kevalidan Lembar Kerja Siswa (LKS) dengan persentase 72,20\% berada pada kriteria Baik (Valid), karena 61\%-80\% masuk dalam klasifikasi Baik .

\section{Revisi Produk}

Berdasarkan hasil peneilaian oleh ahli media pembelajaran (Lembar validasi ahli media) akan dibahas berdasarkan hasil revisi yang telah dilakukan pada validasi ahli media, dimana produk yang direvisi adalah perbaikan dalam desain, pemilihan warna dan bacground. Dalam hal ini akan di tunjukkan hasil revisi sebelum dan sesudah revisi.

1. Halaman Sampul (Cover)

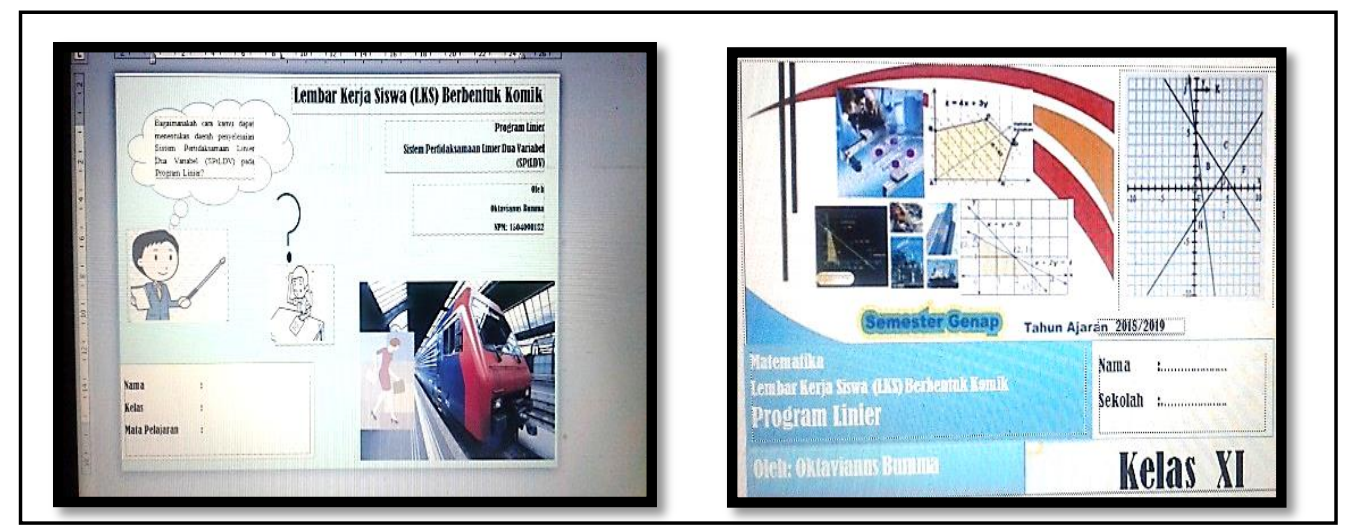

Gambar 1. Cover Sebelum dan Sesudah Revisi

Berdasarkan gambar di atas, halaman sampul masih terlihat baku, sehingga perlu dilakukan revisi.

2. Kata Pengantar, Pada kata pengantar tidak dilakukan revisi sehingga dapat digunakan secara langsung.

3. Daftar isi, Pada daftar isi tidak dilakukan revisi karena sudah sesuai dengan isi Lembar Kerja Siswa (LKS).

4. Lembar isi LKS

Pada isi LKS masih melakukan revisi terhadap materi, desain serta soal yang ada pada LKS.

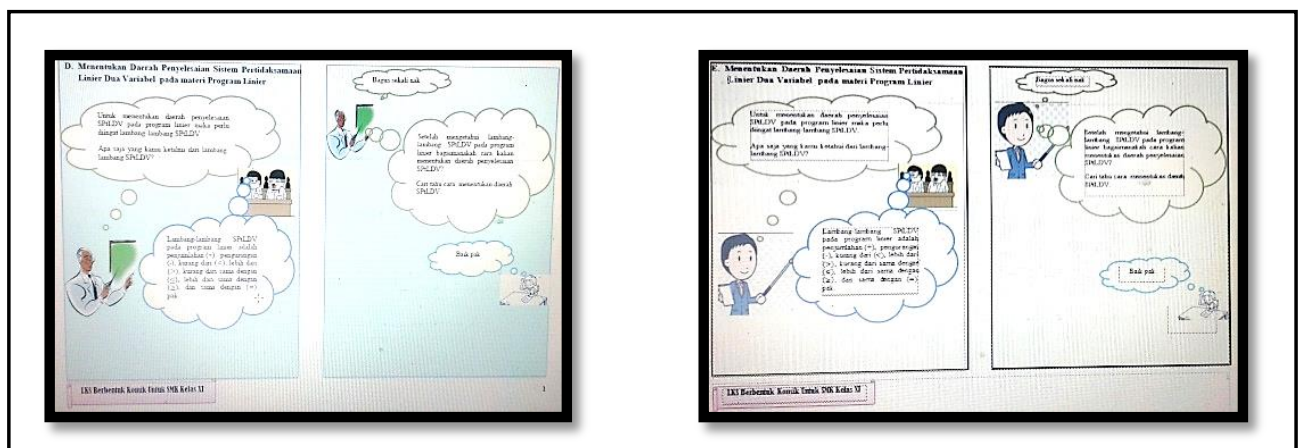

Gambar 2. Sebelum Revisi dan Sesudah Revisi 
5. Uji kompetensi, Pada uji kompetensi tidak dilakukan revisi dan layak di uji cobakan pada peserta didik.

6. Daftar pustaka, Pada daftar pustaka tidak dilkukan revisi dan LKS layak atau valid digunakan dalam pembelajaran matematika.

Penelitian dan pengembangan didefinisikan sebagai studi sistematis terhadap pengetahuan ilmiah yang lengkap atau pemahaman tentang subjek yang diteliti. Penelitian ini diklasifikasikan sebagai dasar atau terapan sesuai dengan tujuan peneitian yaitu untuk mengembangkan Lembar Kerja Siswa (LKS) berbentuk komik berbasis penemuan terbimbing yang valid dan praktis pada materi pembelajaran program linier. Adapaun penelitian yang dimaksud peneliti untuk mengembangkan Lembar Kerja Siswa (LKS) yang valid dan praktis. Untuk menghasilkan produk LKS yang dikembangkan maka peneliti menggunakan prosedur penelitian adalah dengan model ADDIE.

Lembar Kerja Siswa (LKS) yang dikembangkan oleh peneliti dilakukan validasi terhadap tiga validator, yaitu validator ahli materi, validator ahli bahasa dan validator ahli bahasa untuk mengetahui valid atau tidaknya LKS. Hasil yang diperoleh dari hasil validasi menunjukkan bahwa Lembar Kerja Siswa (LKS) yang dikembangkan Valid dan memperoleh kriteri Baik dengan interpetasi 72,20\% sehingga dapat digunakan dalam pembelajaran matematika pada materi program linier pada pokok bahasan Sistem Pertidaksamaan Linier Dua Variabel (SPtLDV). Berdasarkan kriteria Riduwan (2012) LKS dapat dikatan Sangat Valid berdasarkan aspek materi, penyajian, bahasa dan keterbacaan.

Sedangkan untuk mengetahui kepraktisan dari Lembar Kerja Siswa (LKS) berbentuk komik berbasis penemuan terbimbing dengan menggunakan angket/kuisioner respon siswa terhadap LKS dilakukan uji coba terbatas terhadap 10 peserta didik SMK Wisnuwardhana pada kelas XI dan hasilnya Praktis dengan memperoleh rata-rata 3,3. Berdasarkan kriteria oleh Riduwan (2012) dapat dikatakan Sangat Praktis.

Berdasarkan hasil yang didapatkan maka Lembar Kerja Siswa Berbentuk Komik berbasis penemuan terbimbing dalam kategori Valid memiliki kriteria Baik dan dalam kategori Praktis memiliki kriteria Baik. sehingga pengembangan produk Lembar Kerja Siswa (LKS) dapat digunakan dalam pembelajaran matematika.

\section{SIMPULAN}

Pengembangan media Lembar Kerja Siswa (LKS) berbentuk komik berbasis penemuan terbimbing dilakuan melalui tahap-tahap berikut yaitu: 1) penyajian data, 2) analisis data, 3) revisi produk pengembangan. Sasaran pemakaian produk pengembangan adalah guru dan siswa. Tiap tahap LKS dikerjakan dengan baik agar memperoleh hasil yang memuaskan berkualitas dan dapat digunakan dalam pembelajaran matematika.yaitu dapat mencapai tujuan pmbelajaran yang telah ditetapkan. Hasil validasi dan penilaian media Lembar Kerja Siswa (LKS) berbentuk komik berbasis penemuan terbimbing baik dari ahli materi, ahli media dan ahli bahasa serta siswa sebagai pengarah keuputusan yang sama yaitu kelayakanakan media ini. Kelayakan ini dipandang dari berbagai aspek.

Pengembangan media belajar berupa media LKS berbentuk komik berbasis penemuan terbimbing secara aspek menyeluruh diperoleh penilaian $72,20 \%$ yang menyatakan Baik.Validasi terhadap LKS mat ematika dilakukan oleh satu ahli desain media, satu ahli materi dan satu ahli bahasa. Hasil validasi dan penilaian ahli desain media pembelajaran diperoleh persentase $68,33 \%$ berada pada kualitas Baik. Oleh karena itu, dapat disimpulkan bahwa Lembar Kerja Siswa (LKS) berbentuk komik berbass penemuan terbimbing pada materi program linier pada pokok bahasan Sistem Pertidaksamaan Linier Dua Variabel (SPtLDV) in layak digunakan dalam pembelajaran.

Validasi terhadap Lembar Kerj Siswa (LKS) yang dilakukan oleh ahli materi pembelajaran oleh dosen. Hasil validasi dan penilaian ahli materi terhadap Lembar Kerja 
Siswa (LKS) diperoleh persentase keseluruhan sebesar 80\%. Hal ini dapat disimpulkan bahwa Lembar Kerja Siswa (LKS) berada pada kriteria Sangat Baik, sehingga LKS matematika ini layak digunakan dalam proses pembelajaran. Validasi terhadap Lembar Kerja Siswa (LKS) yang digunakan oleh ahli bahasa dosen matematika. Hasil validasi dan penilaian ahli bahasa terhadap bahasa yang digunakan dalam Lembar Kerja Siswa (LKS) diperoleh persentase 78,33\%. Hal ini dapat dismpulkan bahwa Lembar Kerja Siswa (LKS) berada pada kriteria Sangat Baik, sehingga LKS ini layak digunakan dalam pembelajaran.

Pembelajaran dengan penemuan terbimbing memberikan kesempatan kepada siswa untuk menyusun, memproses dan mengorganisir suatu data yang diberikan guru. Melalui proses penemuan ini, siswa di dituntut untuk menemukan ide dan pemahamannya sendiri untuk menemukan sustu yang baru, sehingga pemahaman konsep matematis dapat meningkat. Dengan demikian, pembelajran dengan metode penemuan terbimbing memungkinkan siswa memahami apa yang dipelajari dengan baik.

\section{DAFTAR PUSTAKA}

Abdul, Majid. (2008). Perencanaan Pembelajaran, Mengembangkan Standar Kompetensi Guru. Jakarta: PT. RosdaKarya.

Arikunto. S. (2010). Proedur Penelitian Suatu Pendekatan Praktik. Jakarta: RinekaCipta.

Depdiknas. (2004). Kurikulum 2004 Standar Kompetensi Mata Pelajaran Matematika, Sekolah Menengah Pertama dan Madrasah Tsanawiyah. Jakarta :Depdiknas

Riduwan.2012 Belajar Mudah Peneltian untuk Guru-Karyawan dan Peneliti Pemula. Bandung: Alfabeta

Sudjana, N dan Rifai, A (2011). Media Pengajaran. Bandung: SinarBaru.

Sugiyono. (2010). Metodologi Penelitian Administrasi. Jakarta: CV. Alfabeta. 